\title{
TINGKAT EFISIEN PEMASARAN IKAN LAUT SEGAR DI PELABUHAN PERIKANAN NUSANTARA BRONDONG
}

\section{LEVEL MARKETING EFFICIENT OF FRESH FISH IN BRONDONG FISHING PORT}

\author{
Miftachul Huda ${ }^{1}$, Iin Solihin ${ }^{2}$ Ernani Lubis ${ }^{2}$ \\ ${ }^{1}$ Program Studi Teknologi Perikanan Laut, Sekolah Pascasarjana \\ ${ }^{2}$ Departemen Pemanfaatan Sumberdaya Perikanan \\ Fakultas Perikanan dan Ilmu Kelautan, Institut Pertanian Bogor \\ Korespondensi : mifta.tachul@gmail.com,insol_ipb@yahoo.com
}

\begin{abstract}
Marketing is the key to the sustainability of economic activity is no exception fish catches came from Brondong fishing port. Fish landed in Brondong fishing port is diverse. Spotted big eye fish (Priacanthus tayenus) and yellow goat fish (Upeneus sulphureus) is the dominant fish catches and eastern little tuna (Euthynnus affinis) and red snapper (Lutjanus malabaricus) is an economical high in fish landed in Brondong fishing port. Fishermen in Brondong fishing port average daily fishing 159 tons of fish. The potential magnitude of catches landed in Brondong fishing port must be balanced with good marketing. Marketing activities should be carried out as efficiently as possible so that the business side can provide great benefits from the results of these marketing activities. Fish marketing activities stemming from Brondong fishing port is still inefficient due to marketing activities still using traditional tools. Seeing the condition that it is important to know the level of the efficient marketing activity fish from Brondong fishing port. The aim of this study is to calculate the level of marketing efficiency of fish in Brondong fishing port, Lamongan, East Java. The research will be implemented by the method of the case against the strategy of increasing marketing efficiency of fish from Brondong fishing port. Analysis of the formula used is marketing efficiency. Based on the analysis conducted showed that showed that the existing marketing activity in Brondong fishing port is inefficient. Proved by analysis obtained spotted big eye fish have high levels of Eps 45.44\%, 38.98\% yellow goat fish, eastern little tuna 57.94\% and $25.65 \%$ red snapper with declared where marketing said to be efficient if it has Eps $<5 \%$.
\end{abstract}

Keywords: Brondong fishing port, East Java, fish landed, marketing efficiency

\begin{abstract}
ABSTRAK
Pemasaran merupakan kunci dari keberlanjutan aktivitas perekonomian tidak terkecuali ikan hasil tangkapan yang berasal dari Pelabuhan Perikanan Nusantara (PPN) Brondong. Ikan yang didaratkan di PPN Brondong beragam. Ikan swangi (Priacanthus tayenus) dan ikan kuniran (Upeneus sulphureus) merupakan ikan hasil tangkapan dominan serta ikan tongkol (Euthynnus affinis) dan ikan kakap merah (Lutjanus malabaricus) merupakan ikan ekonomis tinggi yang di daratkan di PPN Brondong. Nelayan PPN Brondong perhari rata-rata melakukan penangkapan ikan 159 ton ikan. Potensi besarnya hasil tangkapan yang didaratkan di PPN Brondong harus dapat diimbangi dengan pemasaran yang baik. Aktivitas pemasaran harus dapat dilakukan se efisien mungkin sehingga dari sisi bisnis dapat memberikan keuntungan yang besar dari hasil kegiatan pemasaran ini. Aktivitas distribusi pemasaran ikan yang berasal dari PPN Brondong saat ini masih belum efisien dikarenakan aktivitas pemasaran masih menggunakan alat-alat yang tradisional. Melihat kondisi itu penting untuk mengetahui tingkat efisien dari aktivitas pemasaran ikan yang berasal dari PPN Brondong. Tujuan dari penelitian ini adalah menghitung tingkat efisiensi pemasaran ikan yang ada di PPN Brondong, Lamongan, Jawa Timur. Penelitian akan dilaksanakan dengan metode kasus terhadap strategi peningkatan efisiensi pemasaran dalam pendistribusian ikan dari Pelabuhan Perikanan Pantai (PPN) Brondong. Analisis yang dipergunakan yaitu dengan rumus efisiensi pemasaran. Berdasarkan analisis yang dilakukan didapatkan hasil yang menunjukkan bahwa aktivitas pemasaran yang ada di PPN Brondong tidak efisien. Terbukti berdasarkan analisis didapatkan ikan swangi memiliki tingkat Eps 45.44\%, ikan kuniran 38.98\%, ikan tongkol 57.94\% dan ikan kakap merah 25.65\% dengan dinyatakan dimana pemasaran dikatakan efisien jika memiliki Eps $<5 \%$.
\end{abstract}

Kata kunci: efisiensi pemasaran, ikan laut segar, Jawa Timur, Pelabuhan Perikanan Nusantara Brondong 


\section{PENDAHULUAN}

Ikan yang didaratkan sangat bervariasi. Beberapa jenis ikan yang didaratkan di PPN brondong diantaranya Ikan tongkol (Euthynnus affinis), ikan kakap merah (Lutjanus campechanus) yang merupakan ikan ekonomis tinggi serta ikan kuniran (Upeneus sulphureus), ikan swangi (Priacanthus tayenus) merupakan hasil tangkapan dominan yang didaratkan di PPN Brondong. Ikan yang berasal dari PPN Brondong ini dipasarkan ke berbagai daerah baik di Lamongan sendiri, kota di sekitar Jawa Timur hingga keluar provinsi Jawa Timur. Ikan yang berasal dari PPN Brondong yang dipasarkan di berbagai tempat memiliki tingkat kenaikan harga yang sangat signifikan. Kenaikan ini disebabkan karena adanya perlakuan untuk kegiatan pemasaran dan pengambilan keuntungan selama ikan didistribusikan. Distribusi merupakan bagian dari pemasaran yang selalu muncul ketika melakukan perpindahan barang dari satu tempat ke tempat yang lainnya dan terjadi pertambahan nilai. Distribusi merupakan faktor penting yang membuat perpindahan barang menjadi cepat (Deswindi 2007).

Ikan yang berasal dari PPN Brondong dipasarkan hampir diseluruh Pulau Jawa dan Bali. Pemasaran dilakukan menggunakan alat transportasi darat berupa truk bak terbuka atau pick-up dimana ikan dimasukkan ke dalam drum ataupun palka fiber yang diletakkan diatas kendaraan. Proses pemasaran ikan yang berasal dari PPN Brondong melalui cukup banyak tangan/pelaku atau juga yang biasa disebut rantai pasok. Panjangnya rantai yang dilalui ini membuat pemasaran ikan yang berasal dari PPN Brondong menjadi tidak efisien.

Tidak efisiennya pemasaran ikan yang berasal dari PPN Brondong disebabkan oleh banyaknya jumlah rantai atau pelaku (rantai pemasaran) yang berkecimpung dalam distribusi proses pemasaran ikan. Jumlah rantai pemasaran yang dilewati oleh suatu komoditas dalam proses pemasaran mempengaruhi terhadap harga ikan karena adanya pengambilan keuntungan oleh setiap pelaku. Rantai pemasaran mencakup semua link dari titik produksi (proses penangkapan ikan) kepada pengguna akhir atau konsumen akhir. Rantai pasok berisi kumpulan subpasar atau sistem pemasaran. Sebuah sistem pemasaran didefinisikan sebagai mata rantai hubungan antara produsen/ pemasok dan konsumen, termasuk semua mekanisme yang menentukan hubungan antara laba produsen dan penyediaan produk fisik (Cenini 2012).

Melihat tidak efisiennya kegiatan pemasaran ikan yang berasal dari PPN Brondong ini, maka perlu diketahui tingkat kenaikan harga (margin) ikan yang dipasarkan sehingga dapat diketahui tingkat efisien dari kegiatan pemasaran ikan yang berasal dari PPN Brondong.

\section{METODE PENELITIAN}

Penelitian ini dilakukan di PPN Brondong, Pasar Pabean Surabaya (pasar induk), Pasar Larangan Sidoarjo (pasar kabupaten), dan Pasar Wonoayu (pasar kecamatan/desa). Penelitian dilakukan pada bulan November-Desember 2014. Pengambilan data dilakukan dengan metode purposive sampling yaitu melakukan wawancara langsung dengan para pelaku yang ada di setiap lokasi pemasaran ikan. Wawancara dilakukan terhadap 5 responden nelayan, 5 pemborong, 5 distributor, 5 sopir, 3 pedagang di pasar regional, 3 pedagang pasar kabupaten/kota dan 3 pedagang pasar kecamatan. Penentuan jumlah responden diatas dikarenakan telah memiliki kesamaan informasi, sehingga informasi sudah dianggap cukup karena saling melengkapi dari responden yang sebelumnya.

Pengambilan data meliputi harga ikan yang dijual, besar pengambilan keuntungan, tingkat kenaikan harga di setiap pelaku, serta biaya produksi yang dikeluarkan oleh setiap pedagang atau distributor. Menurut Hapsari (2013), untuk mengetahui jumlah rantai dan margin pemasaran ikan diperlukan data meliputi harga ikan; saluran pemasaran ikan; margin pemasaran ikan; biaya produksi pada pedagang pengecer dan pedagang besar ikan; dan keuntungan yang didapatkan oleh pedagang pengecer dan pedagang besar. Setelah ditemukan alur pemasaran termasuk jumlah pelaku dan besarnya margin yang terjadi, maka akan didapatkan tingkat efisien dari pemasaran ikan yang berasal dari PPN Brondong.

Efisien menurut kamus besar bahasa Indonesia yaitu tepat atau sesuai untuk mengerjakan (menghasilkan) sesuatu (dengan tidak membuang-buang waktu, tenaga, biaya), mampu menjalankan tugas dengan tepat dan cermat, berdaya guna, bertepat guna. Efisien artinya melakukan sesuatu dengan sumber daya yang hemat atau dengan tanpa pemborosan, sedangkan 
efisiensi adalah penggunaan sumber daya secara minimum guna pencapaian hasil yang optimum (Anggrahini 2012).

Menurut Hanafiah \& Saefuddin (2006), efisiensi tata niaga dianalisis berdasarkan efisiensi teknis dan ekonomis. Efisiensi teknis dipilih karena memiliki kriteria yang jelas meliputi input pendapatan dan biaya barang yang dipasarkan hingga output dari barang yang dipasarkan. Pengukuran efisiensi ekonomis menggunakan margin rantai nilai yang ada di pasar sebagai alat ukurnya. Efisiensi teknis merupakan pengendalian fisik dari produk atau komoditas yang mencakup prosedur, teknis, dan besarnya skala operasi. Tujuan dari efisiensi teknis ini untuk penghematan fisik seperti mengurangi kerusakan barang, mencegah merosotnya mutu produk, dan menghemat tenaga kerja yang akan berdampak pengurangan ongkos berupa uang yang tergantung pada economic environment dalam rantai nilai yang berlangsung. Efisiensi ekonomis menunjukkan bahwa perusahaan atau industri dengan teknik, keahlian dan pengetahuan yang ada, dapat bekerja atas dasar biaya rendah dan memperoleh keuntungan.

Margin pemasaran adalah perbedaan harga antara yang harus dibayar kepada penjual pertama dan harga yang dibayar oleh pembeli terakhir. Menurut Oktariza (1996), untuk menghitung margin pemasaran dapat menggunakan rumus:

$$
\mathrm{MP}=H K-H P
$$

dimana :

MP : margin pemasaran

$H K$ : harga ditingkat konsumen

$H P$ : harga ditingkat nelayan

Efisiensi pemasaran merupakan maksimisasi rasio antara luaran dan masukan yang digunakan dalam kegiatan pemasaran (Irawan 2007). Menurut (Rasyaf 1995) dalam (Rasuli 2007), biaya pemasaran adalah biaya-biaya yang dikeluarkan dalam pergerakan barang dari tangan produsen sampai konsumen akhir atau setiap biaya yang dikeluarkan untuk keperluan pemasaran. Biaya pemasaran adalah semua biaya yang terjadi sejak produk selesai diproduksi dan disimpan dalam gudang dan sampai saat produk diubah kembali dalam bentuk tunai. Biaya pemasaran merupakan biaya yang dikeluarkan dalam memasarkan, mendistribusikan, dan melayani produk atau jasa (Setiawan 2014).
Biaya pemasaran meliputi biaya operasional pemasaran yang dikeluarkan pedagang (biaya pengangkutan, penyimpanan, sortasi, grading) dan keuntungan pedagang (Irawan, 2007). Menurut Hapsari (2013), untuk mengetahui tingkat efisiensi pemasaran Ikan pada masing-masing lembaga pemasaran, digunakan rumus sebagai berikut:

$\mathrm{EPs}=\frac{B_{p}}{H E} \times 100 \%$

dimana:

Eps : efisiensi pemasaran

$\mathrm{Bp} \quad$ : biaya pemasaran

$H E$ : harga eceran

Kriteria:

- Eps $<5 \%$, berarti efisien

- Eps $>5 \%$, berarti tidak Efisien

\section{HASIL DAN PEMBAHASAN}

\section{Alur dan lokasi pemasaran}

Berdasarkan observasi dan wawancara di PPN Brondong yang termasuk ikan ekonomis tinggi yaitu ikan tongkol dan ikan kakap merah, serta ikan kuniran dan ikan swangi merupakan ikan dominan. Bentuk pemasaran tersebut tertera pada Tabel 1 .

Masing-masing pemasaran ikan memiliki alur yang berbeda-beda. Khusus ikan swangi dan ikan kuniran yang merupakan bahan baku untuk surimi, memiliki alur pendistribusian yang sama yaitu dibawa menuju pabrik pengolahan yang ada di sekitar PPN Brondong (Tabel 2). Ikan swangi dan ikan kuniran diolah di pabrik, nantinya setelah diolah akan langsung dipasarkan keluar negeri untuk memenuhi pasar ekspor.

Alur pemasaran ikan swangi dan ikan kuniran memiliki kesamaan. Kesamaan ini dikarenakan kedua ikan ini merupakan bahan pokok untuk dijadikan surimi oleh perusahaan yang ada disekitar PPN Brondong dan sebagian lgi dijual dalam bentuk ikan segar. Ikan swangi dan kuniran yang berbentuk segar di pasarkan di kota Lamongan, Sidoarjo, Tuban, Bojonegoro dan juga Surabaya.

Ikan tongkol dan ikan kakap merah yang ada di PPN Brondong tidak semua berasal dari kapal yang mendarat di PPN Brondong, namun sebagian berasal dari pangkalan pendaratan ikan (PPI) yang ada disekitar PPN Brondong. Seperti ikan tongkol yang berasal dari PPI Labuhan serta ikan kakap merah dari PPI Kandang Semangkon dan PPI Kranji (Gambar 2). 
Ikan tongkol memiliki daerah pemasaran yang cukup luas meliputi Bojonegoro, Tuban, Lamongan, Surabaya, Sidoarjo, Pasuruan dan Malang (Gambar 3). Ikan tongkol dipasarkan dalam bentuk segar karena dijual di pasar tradisional dan dipergunakan untuk konsumsi rumah tangga.

Ikan tongkol dalam proses pemasarannya menuju konsumen di daerah, setidaknya melalui 5 rantai sebelum sampai konsumen (Gambar 4). Rantai pemasaran yang cukup panjang ini disebabkan adanya titik lokasi yang merupakan pusat pemasaran ikan skala besar. Lokasi yang menjadi pusat pemasaran ikan skala besar yang ada di Jawa Timur yaitu Pasar Pabean yang ada di Kota Surabaya.

Ikan kakap merah memiliki pasar tersendiri dan dipasarkan dalam bentuk fillet serta dikonsumsi segar utuh. Pemasaran ikan kakap meliputi Surabaya dan Sidoarjo (Gambar 5) untuk masuk di perusahaan fillet ikan, dan Singaraja-Bali untuk dijadikan konsumsi ikan segar utuh di restoran.

Sama halnya dengan ikan tongkol, ikan kakap merah setidaknya untuk mencapai konsumen dalam bentuk segar setidaknya membutuhkan 5 rantai hingga sampai ditangan konsumen (Gambar 6). Namun ada juga yang mencapai 6 rantai karena dijual di restoran-restoran yang ada di sekitar tempat wisata di pulau Bali.

\section{Margin pemasaran dan efisiensi pemasaran}

Panjangnya alur pemasaran ikan yang dilakukan oleh pelaku menjadikan adanya kenaikan harga akibat adanya margin dari ikan yang dipasarkan. Setiap perpindahan pelaku yang dilalui sampai ke konsumen atau pembeli terakhir memerlukan atau menimbulkan adanya margin. Margin pemasaran ikan dari setiap jenis ikan berbeda-beda tergantung dari harga ikan itu sendiri ketika pertama kali di jual oleh nelayan dan juga jumlah pelaku yang ada didalamnya.

\section{Ikan swangi dan ikan kuniran}

Ikan swangi dan kuniran memiliki tingkat margin yang sama dalam aktivitas distribusi pemasaran. Margin yang sama ini dikarenakan harga ikan cenderung ditentukan oleh pabrik berdasarkan pada stok ikan yang didaratkan (Tabel 3). Fluktuatif harga sangat tinggi karena ikan yang didaratkan di PPN Brondong dalam pembongkarannya bergantian, sehingga harga ikan akan berfluktuatif sesuai kapasitas produksi dari perusahaan pengolahan ikan yang ada di PPN Brondong (Tabel 4).

Berdasarkan Tabel 3 dan 4 terlihat adanya margin yang terjadi dari proses pemasaran ikan swangi dan ikan kuniran. Ikan swangi dan kuniran mengalami margin dari masing-masing ikan mencapai 2.500/ $\mathrm{kg}$. Berdasarkan hasil wawancara, margin kenaikan harga ikan yang terjadi pada ikan swangi dan ikan kuniran disebabkan karena pemberian es curah, upah sopir, sewa mobil dan biaya resiko. Namun, untuk tingkat efisiensi pemasaran mengalami perbedaan karena memiliki harga awal ikan yang berbeda. Ikan swangi memiliki tingkat efisiensi pemasaran mencapai $(45.64 \%)$ sedangkan ikan kuniran mencapai (38.98\%).

\section{Ikan tongkol}

Margin ikan tongkol memiliki perbedaan dengan ikan kuniran dan ikan swangi. Perbedaan ini dikarenakan jumlah rantai yang harus dilalui oleh ikan ini sendiri untuk mencapai konsumen akhir juga lebih panjang. Ikan tongkol harus melalui 5 rantai atau pelaku yang di setiap pelaku terjadi margin pemasaran yang disebabkan adanya pengambilan keuntungan dan biaya pemasaran ikan.

Berdasarkan Tabel 5 terlihat bahwa dalam pemasaran ikan tongkol terjadi 4 kali proses kenaikan harga dikarenakan harus melalui 5 pelaku yang berbeda sebelum diterima konsumen. Komoditas ikan tongkol terjadi margin sebesar $17.000 / \mathrm{kg}$ ketika di pasar kecamatan atau pasar desa. Adanya margin yang terjadi pada komoditas ikan tongkol ini disebabkan oleh pengambilan keuntungan, pemberian perlakuan untuk menjaga kualitas ikan, biaya transportasi selama distribusi, dan biaya resiko ikan yang tidak terjual. Tingkat efisiensi pemasaran dari ikan tongkol sendiri mencapai (57.94\%) yang menunjukkan bahwa sistem pemasaran yang ada belum efisien.

\section{Ikan kakap merah}

Ikan kakap merah juga memiliki margin yang berbeda dengan ikan tongkol, ikan kuniran dan ikan swangi. Perbedaan ini dikarenakan jumlah rantai yang harus dilalui oleh ikan ini sendiri untuk mencapai konsumen akhir juga lebih 
panjang dan harga ikan ini yang lebih mahal. Ikan kakap merah harus melalui 5 rantai atau pelaku yang disetiap pelaku terjadi margin pemasaran yang disebabkan adanya pengambilan keuntungan dan biaya pemasaran ikan.

Berdasarkan Tabel 6 terlihat bahwa dalam pemasaran ikan kakap sama dengan ikan tongkol terjadi 4 kali proses kenaikan harga dikarenakan harus melalui 5 pelaku yang berbeda sebelum mencapai tangan konsumen. Komoditas ikan kakap merah terjadi margin sebesar $22.000 / \mathrm{kg}$ ketika di pasar kecamatan atau pasar desa. Adanya margin yang terjadi pada komoditas ikan kakap merah ini disebabkan oleh pengambilan keuntungan, pemberian perlakuan untuk menjaga kualitas ikan, biaya transportasi selama distribusi, dan biaya resiko ikan yang tidak terjual. Tingkat efisiensi pemasaran dari ikan kakap merah sendiri mencapai $29.58 \%$ yang menunjukkan bahwa sistem pemasaran yang ada belum efisien.

\section{Faktor penyebab kenaikan harga ikan dan biaya pemasaran}

Banyak faktor yang menyebabkan terjadinya kenaikan harga pada ikan yang dipasarkan. Masing-masing ikan memiliki penyebab adanya kenaikan harga. Pelaku dalam alur distribusi ikan dalam proses pemasaran menjadi pihak yang menyebabkan margin tersebut. Ini terlihat dari beberapa ikan yang terdapat dibawah ini.

\section{Ikan swangi dan ikan kuniran}

Ikan swangi dan ikan kuniran yang memiliki rantai pemasaran paling pendek cukup banyak faktor yang menyebabkan munculnya margin pemasaran. Faktorfaktor tersebut meliputi dari pihak nelayan dan pihak distributor.

Harga dimulai dari penjualan di TPI. Penambahan biaya pemasaran juga bertambah ketika sampai di tangan distributor. Penambahan itu meliputi biaya pemberian es, biaya kuli angkut dari TPI ke mobil pick-up, biaya sopir, biaya resiko dan biaya retribusi pembelian ikan.

\section{Ikan tongkol}

Ikan tongkol yang memiliki rantai pemasaran cukup panjang membuat munculnya margin pemasaran yang cukup besar pula. Faktor-faktor tersebut meliputi pihak nelayan, pihak distributor, pihak pedagang ikan di pasar regional, pedagang di pasar kabupaten, dan pedagang di pasar kecamatan/desa berlomba-lomba mempertahankan kualitas ikan yang mengakibatkan meningkatnya margin.

Harga bermula dari penjualan di TPI. Biaya pemasaran juga terjadi di pihak distributor yang menyebabkan terjadinya margin karena harus mengeluarkan biayabiaya lain pula. Biaya yang dikeluarkan meliputi membayar jasa pikul dari TPI menuju pick-up, pemberian es untuk ikan, biaya bahan bakar minyak kendaraan, upah sopir, pengambilan keuntungan, biaya retribusi pembelian ikan dari TPI dan biaya resiko. Biaya yang dikeluarkan tidak sampai disini, karena masih ada penanganan dan pengambilan keuntungan yang harus diperoleh oleh pedagang di pasar regional, pasar kabupaten dan pasar kecamatan, maka terjadi pula kenaikan harga ikan di setiap pelaku-pelaku yang ada didalam alur distribusi ikan ini.

\section{Ikan kakap merah}

Ikan kakap merah yang memiliki rantai pemasaran cukup panjang membuat munculnya margin pemasaran yang cukup besar pula. Faktor-faktor tersebut meliputi dari pihak nelayan, pihak distributor, pihak pedagang ikan di pasar regional, pedagang di pasar kabupaten, dan pedagang di pasar kecamatan/desa berlomba-lomba mempertahankan kualitas ikan yang mengakibatkan margin harga ikan sendiri.

Penyebab munculnya harga dimulai dari harga penjualan di TPI. Biaya pemasaran juga terjadi di pihak distributor yang menyebabkan terjadinya margin karena harus mengeluarkan biaya-biaya lain pula. Biaya yang dikeluarkan meliputi membayar jasa pikul dari TPI menuju pickup, pemberian es untuk ikan, biaya bahan bakar minyak kendaraan, upah sopir, pengambilan keuntungan, biaya retribusi pembelian ikan dari TPI dan biaya resiko. Biaya yang dikeluarkan tidak sampai disini, karena masih ada penanganan dan pengambilan keuntungan yang harus diperoleh oleh pedagang di pasar regional, pasar kabupaten dan pasar kecamatan, maka terjadi pula kenaikan harga ikan di setiap pelaku-pelaku yang ada didalam alur distribusi ikan ini. 


\section{Pembahasan}

Lokasi pemasaran dan jumlah pelaku yang ada dalam satu alur pemasaran ikan menjadi kunci dari tingkat margin dan efisiensi pemasaran yang terjadi pada komoditas ikan yang berasal dari PPN Brondong. Menurut Sobariah dan Ganjar (2013), salah satu penyebab terjadinya kesenjangan penerimaan keuntungan adalah karena rantai pemasaran yang masih terlalu panjang dimana dari produsen ke pedagang pengumpul, pedagang pengumpul ke pedagang besar, pedagang besar ke pengecer, dari pengecer baru sampai ke konsumen akhir dalam hal ini pembeli.

Banyaknya pelaku yang berkecimpung dalam alur pemasaran ini membuat semakin membengkaknya harga ikan yang ada di pasaran. Terutama untuk ikan tongkol dan ikan kakap merah yang merupakan ikan ekonomis tinggi, daerah pemasaran ikan yang sangat menyebar dan membutuhkan banyak pelaku untuk sampai ke konsumen membuat terjadinya margin yang sangat besar. Menurut Sobariah dan Ganjar (2013), komponen margin pemasaran terdiri dari biaya-biaya yang diperlukan oleh lembaga-lembaga pemasaran untuk melakukan fungsi-fungsi pemasaran yang disebut dengan biaya pemasaran atau biaya fungsional dan keuntungan lembaga pemasaran. Pada gambar 7 menunjukkan bahwa jumlah rantai mempengaruhi margin ikan yang dipasarkan. Hal ini karena adanya perlakuan dan pengambilan keuntungan oleh setiap pelaku yang ikut melakukan aktivitas pemasaran ikan. Menurut Hapsari (2013), margin pemasaran jumlah produksi, harga per kilogram, biaya pemasaran dan musim adalah faktor-faktor yang mempengaruhi margin pemasaran ikan.

Margin pada kegiatan pemasaran yang bergantung jumlah rantai diperkuat pula berdasarkan penlitian yang dilakukan oleh Tahir (2010) dimana pedagang perantara mengeluarkan biaya dalam rangka penyelenggaraan kegiatan pemasaran hingga ke konsumen. Besarnya biaya yang dikeluarkan bagi tiap-tiap saluran pemasaran selalu berbeda-beda. Dengan demikian semakin panjang saluran pemasaran maka jumlah biaya yang dikeluarkan akan semakin bertambah. Menurut Ahmad (2013) sistem pemasaran dewasa ini dimainkan oleh para pelaku produsen atau nelayan, nelayan yang memiliki beban hutang harus menjual melalui tengkulak terlebih dahulu yang membuat semakin panjangnya rantai yang dilalui untuk bisa mencapai konsumen. Hal ini membuat rantai pemasaran menjadi panjang dan tidak efisien. Menurut Johanson (2013), Harga yang ditawarkan oleh pengumpul kepada nelayan berbedabeda sesuai dengan tingkatan pengumpul atau daerah pemasaran. Harga yang berlaku adalah hasil kesepakatan antara nelayan dan pengumpul yang masing-masing pihak telah mempertimbangkan waktu, tenaga, biaya dan keuntungan.

Tingkat efisiensi pemasaran ikan yang berasal dari PPN Brondong juga tergolong masih belum efisien. Tidak efisiennya pemasaran ditunjukkan dengan tingkat efisiensi pemasaran dari setiap ikan memiliki nilai Eps > 5\% yang menunjukkan bahwa efisiensi pemasaran tergolong tidak efisien. Menurut Hapsari (2013), untuk mengetahui tingkat efisiensi pemasaran Ikan pada masing-masing lembaga pemasaran, dapat diberikan kriteria apabila Eps $<5 \%$ maka dinyatakan efisien, dan jika Eps $>5 \%$ maka dinyatakan belum efisien.

Setiap ikan yang dipasarkan memiliki tingkat kenaikan harga yanng berbeda tergantung dari jenis ikan, harga ikan yang ada di tingkat nelayan serta dari penanganan yang diberikan selama proses pemasaran. Pada ikan swangi dan ikan kuniran ikan yang berasal dari nelayan dibeli oleh supplyer yang langsung dibawa menuju pabrik pengolahan memiliki harga yang berbeda. Perbedaan harga terjadi ditingkat nelayan karena jenis ikan kuniran memiliki nilai ekonomis yang lebih tinggi. Sedangkan untuk margin dari ikan swangi mengalami kenaikan harga yang sama karena penanganan yang diberikan dalam proses pemasaran sama yaitu berupa pemberian es sebelum ikan dibawa menuju pabrik.

Ikan tongkol dan kakap merah merupakan ikan ekonomis tinggi memiliki margin yang berbeda meskipun jumlah rantai pemasaran yang dilewati sama. Tingkat ekonomis dan penanganan yang diberikan pada ikan berbeda membuat harga masing-masing ikan mengalami kenaikan harga yang berbeda pula. Ikan kakap merah menjadi ikan yang memiliki harga lebih tinggi dibandingkan dengan tongkol ini dikarenakan permintaan dan pangsa pasar yang berbeda. Ikan tongkol biasa dipasarkan hanya dalam bentuk segar utuh dan dijual di pasar tradisional. Sedangkan untuk ikan kakap merah pemasaran meliputi ikan segar utuh yang dipasarkan baik di pasar 
tradisional maupun restoran. Selain itu, ikan kakap merah juga dipasarkan dalam bentuk fillet yang kemudian diekspor menuju negara-negara sekitar indonesia untuk dipasarkan di supermarket.

Kenaikan harga masing-masing ikan terjadi tertinggi di rantai kedua dimana merupakan ditingkat supplyer karena adanya pemberian penanganan pada ikan sebelum dipasarkan menuju lokasi pasar masing-masing. Prosentase kenaikan harga pada setiap ikan ditingkat supplyer diantaranya Ikan swangi $23 \%$, kuniran $19 \%$, kakap merah $10 \%$, dan ikan tongkol mencapai $41 \%$. Pada lokasi yang sama di PPN Brondong menurut Ayuanita dan Ubaidillah (2012), komoditas ikan bawal putih mengalami kenaikan tertinggi pada rantai kedua yaitu pedagang pengumpul (agen) yang mencapai (53\%) (Gambar 7).

Tingkat efisiensi pemasaran ikan yang berasal dari PPN Brondong untuk jenis ikan swangi, kuniran, tongkol dan kakap merah masih berada pada tingkat tidak efisien. Berdasarkan hasil analisis efisiensi pemasaran ikan, ikan swangi, kuniran, tongkol, dan kakap merah memiliki nilai efisiensi pemasaran (Eps) masing-masing $45.44 \%$, 38.98\%, 57.94\% dan 25.3\%. Nilai Eps ini menunjukkan bahwa pemasaran ikan yang berasal dari PPN Brondong dengan komoditas 4 ikan tersebut masih belum efisien. hal ini dikarenakan suatu produk dinyatakan efisien jika nilai efisiensi pemasaran kurang dari 5\% (Eps $<5 \%$ ) (Tabel 10).

Tabel 1. Pemanfaatan ikan yang dipasarkan

\begin{tabular}{cll}
\hline No. & \multicolumn{1}{c}{ Nama Ikan } & \multicolumn{1}{c}{ Pemanfaatan } \\
\hline 1. & Ikan tongkol & Konsumsi segar utuh \\
2. & Ikan kakap merah & Konsumsi segar utuh dan fillet \\
3. & Ikan swangi & Surimi dan konsumsi segar utuh \\
4. & Ikan kuniran & Surimi dan konsumsi segar utuh \\
\hline
\end{tabular}

Tabel 2. Nama perusahaan pengolahan ikan di sekitar PPN Brondong

\begin{tabular}{cll}
\hline No & \multicolumn{1}{c}{ Nama Perusahaan } & \multicolumn{1}{c}{ Produksi Olahan } \\
\hline 1. & PT. HATNI & Ikan fillet beku \\
2. & PT. ANELA & Surimi dan Ikan beku \\
3. & CV. SINDI PRATAMA & Surimi dan Ikan Beku \\
4. & PT. 88 & Surimi dan Ikan Beku \\
5. & PT. 689 & Ikan Beku dan Ikan Olahan \\
6. & PT. STARFOOD & Surimi dan Ikan Beku \\
\hline
\end{tabular}

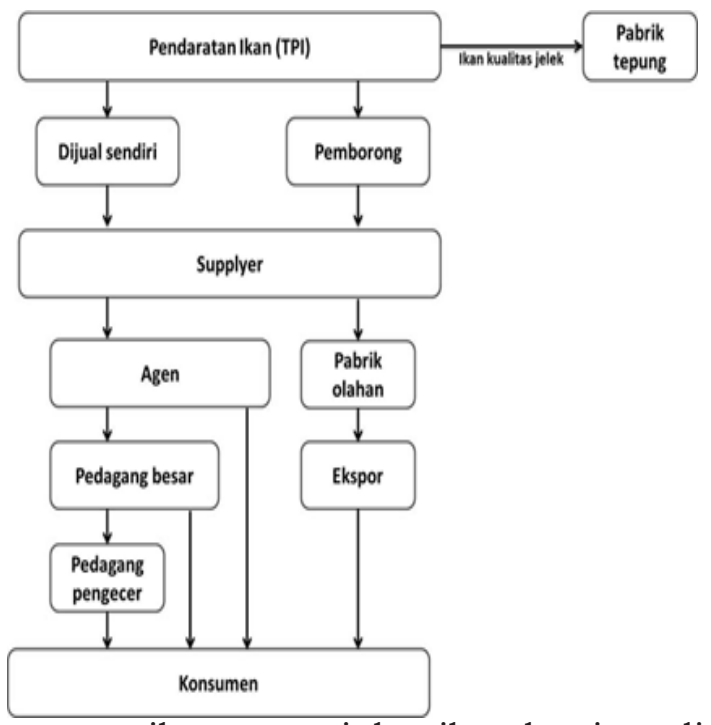

Gambar 1. Alur pemasaran ikan swangi dan ikan kuniran di PPN Brondong 


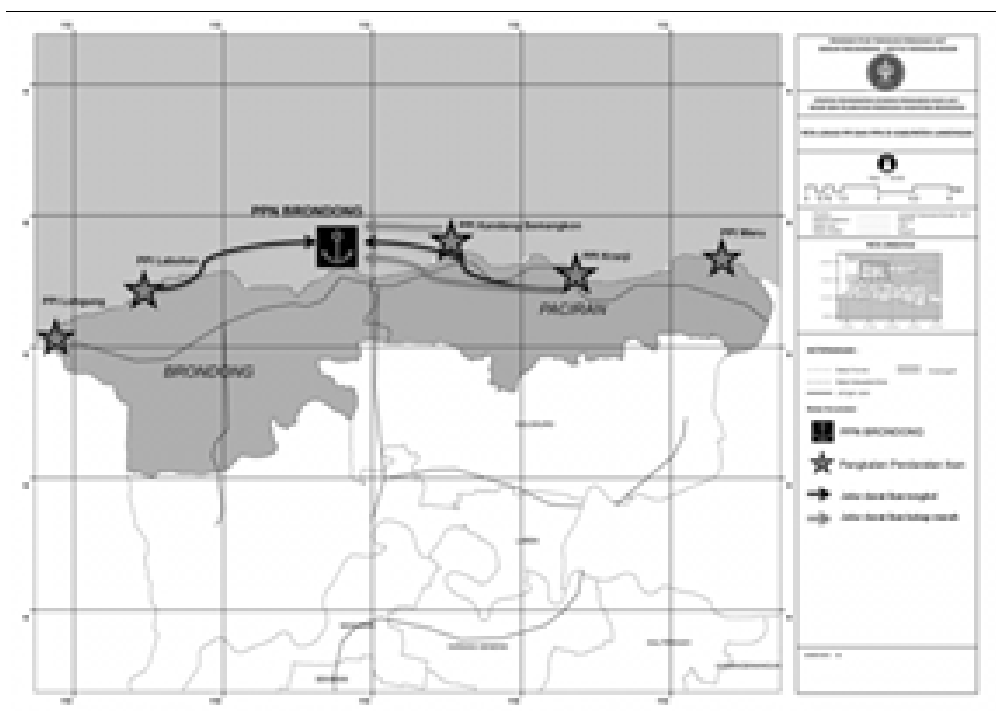

Gambar 2. Ikan yang masuk PPN Brondong dari jalur darat

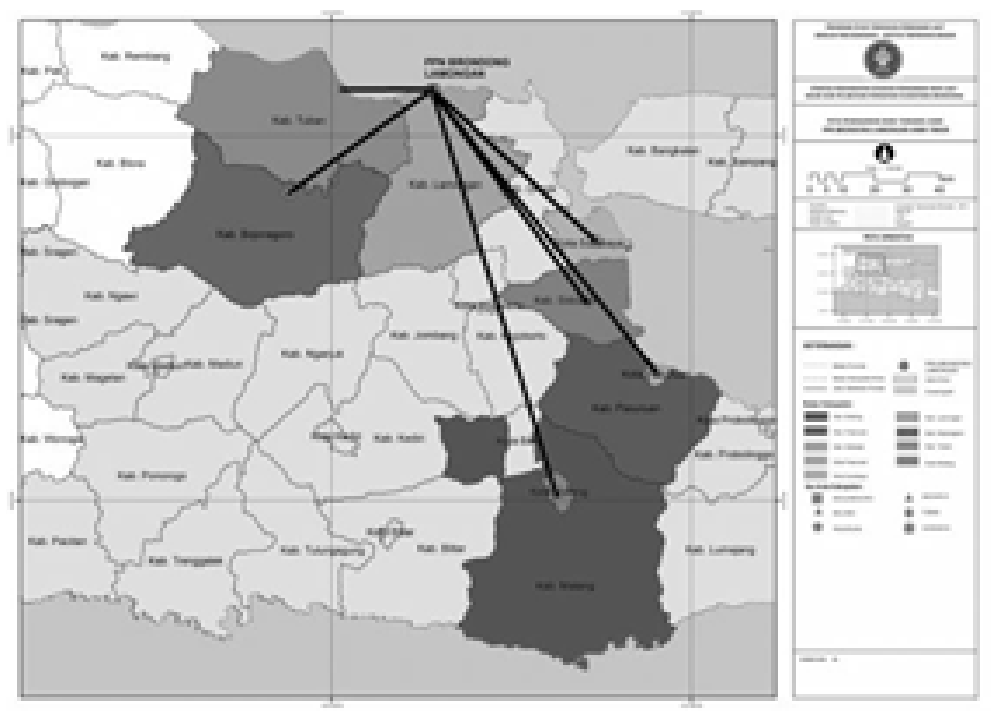

Gambar 3. Kota tujuan pemasaran ikan tongkol

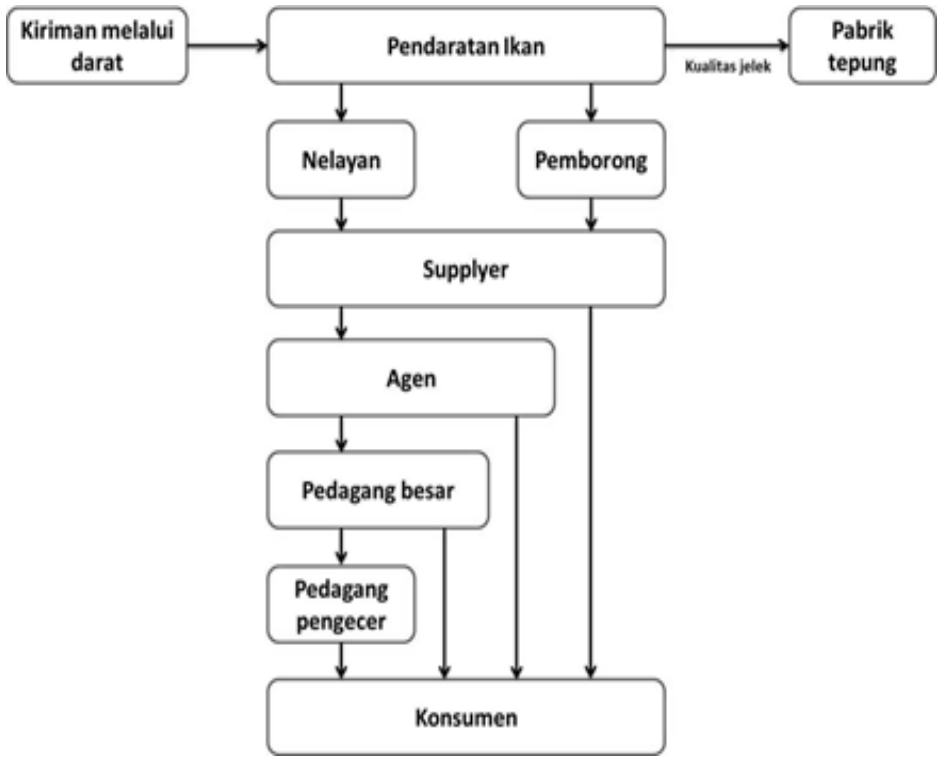

Gambar 4. Alur pemasaran ikan tongkol dari PPN Brondong 


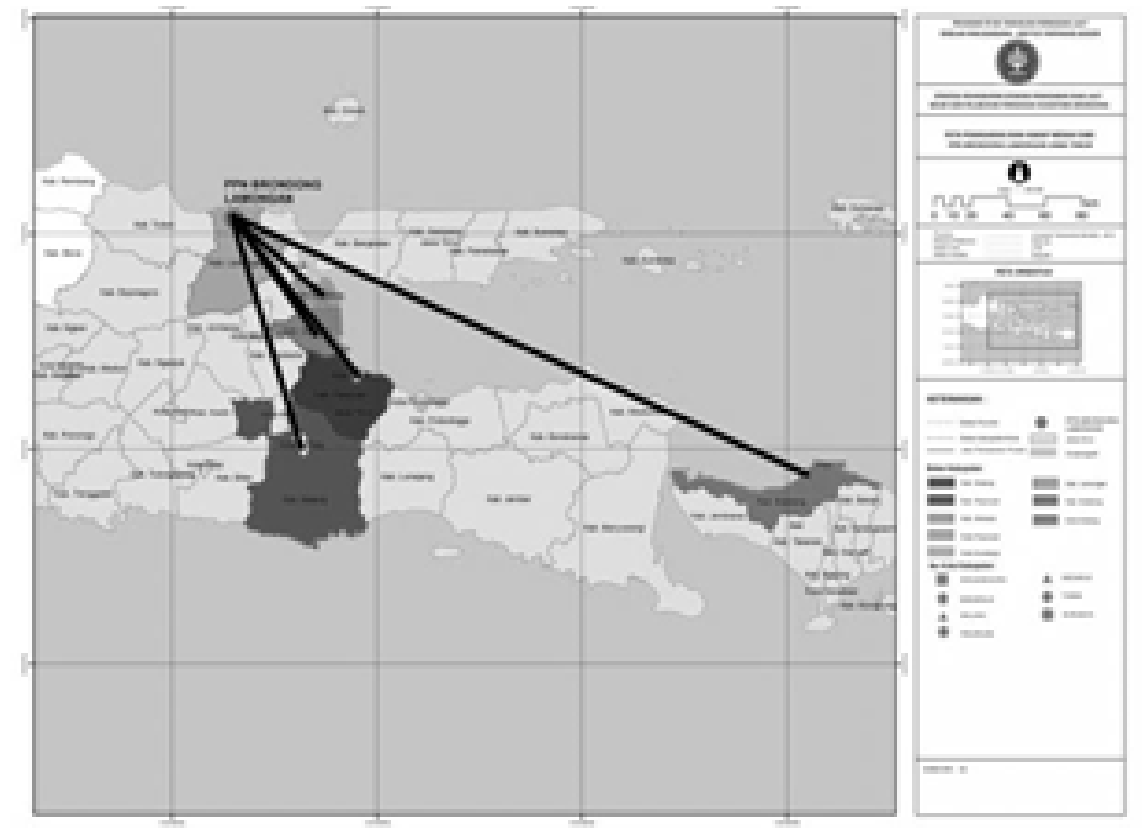

Gambar 5. Kota tujuan pemasaran ikan kakap merah

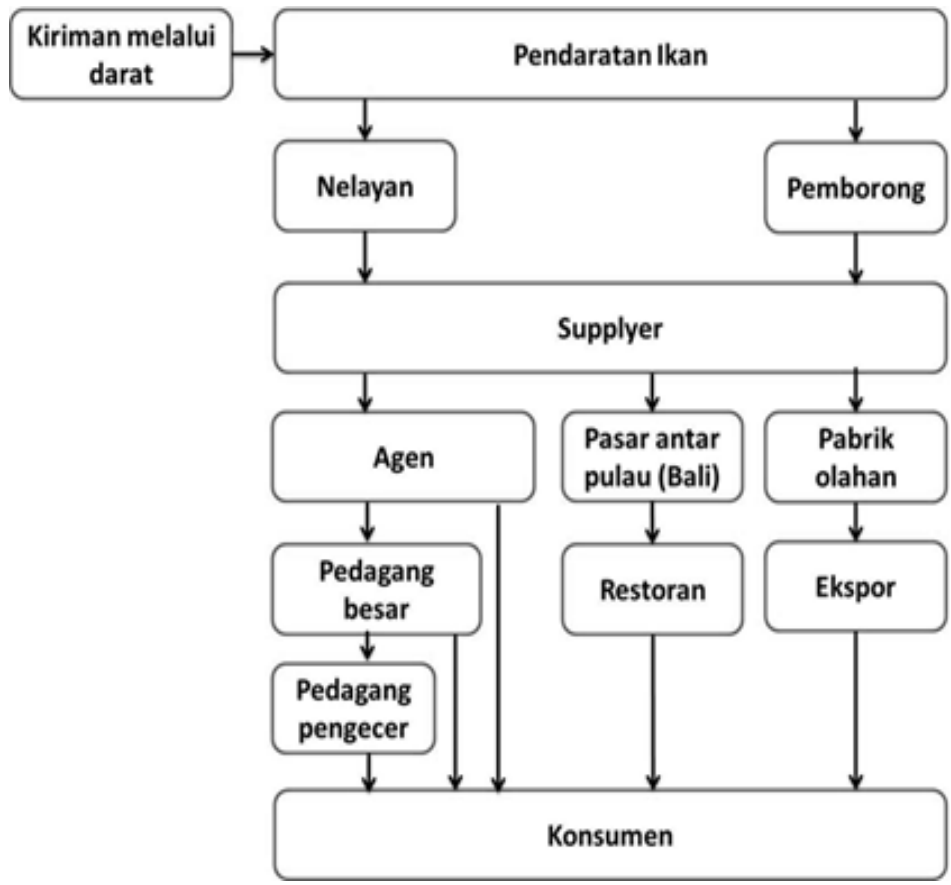

Gambar 6. Alur pemasaran ikan kakap merah 
Tabel 3. Margin harga ikan swangi dan tingkat efisiensi

\begin{tabular}{cllll}
\hline No. & Rantai & Rata-rata Harga & $\begin{array}{c}\text { Tingkat Kenaikan } \\
\text { Harga }\end{array}$ & $\begin{array}{c}\text { Efisiensi } \\
\text { Pemasaran (Eps) }\end{array}$ \\
\hline 1 & R1 & Rp1 1.000 & & $45.64 \%$ \\
2 & R2 & Rp 13.500 & Rp 2.500 & \\
Margin & Rp 2.500 & & \\
\hline
\end{tabular}

Keterangan: R1 = Produsen (nelayan/pemborong); R2 = Distributor/Supplyer utusan Pabrik

Tabel 4. Margin harga ikan kuniran dan tingkat efisiensi

\begin{tabular}{clllc}
\hline No & Rantai & Rata-rata Harga & $\begin{array}{c}\text { Tingkat Kenaikan } \\
\text { Harga }\end{array}$ & $\begin{array}{c}\text { Efisiensi } \\
\text { Pemasaran (Eps) }\end{array}$ \\
\hline 1 & R1 & Rp 13.125 & & $39.91 \%$ \\
2 & R2 & Rp 15.625 & Rp 2.500 & \\
Margin & Rp 2.500 & & \\
\hline
\end{tabular}

Tabel 5. Margin harga ikan tongkol dan efisiensi pemasaran

\begin{tabular}{|c|c|c|c|c|c|}
\hline \multirow{2}{*}{$\frac{\text { No }}{1}$} & \multirow{2}{*}{$\begin{array}{l}\text { Rantai } \\
\text { R1 }\end{array}$} & \multirow{2}{*}{$\begin{array}{l}\text { Rata-rata Harga } \\
\text { Rp } 9.775\end{array}$} & \multicolumn{2}{|c|}{$\begin{array}{c}\text { Tingkat Kenaikan } \\
\text { Harga }\end{array}$} & \multirow[t]{2}{*}{$\begin{array}{c}\text { Efisiensi } \\
\text { Pemasaran (Eps) }\end{array}$} \\
\hline & & & & & \\
\hline 2 & $\mathrm{R} 2$ & $\mathrm{Rp} \quad 13.775$ & $\mathrm{Rp}$ & 4.000 & \\
\hline 3 & R3 & Rp 18.775 & $\mathrm{Rp}$ & 5.000 & $57.94 \%$ \\
\hline 4 & $\mathrm{R} 4$ & Rp 22.775 & $\mathrm{Rp}$ & 4.000 & \\
\hline \multirow[t]{2}{*}{5} & R5 & Rp 26.775 & $\mathrm{Rp}$ & 4.000 & \\
\hline & Margin & Rp 17.000 & & & \\
\hline
\end{tabular}

Keterangan: R1 : Produsen (nelayan/pemborong); R2 : Distributor/Supplyer; R3 : Agen Pasar Regional (Pasar Pabean Surabaya); R4 : Pedagang besar Pasar Kabupaten (Pasar Larangan Sidoarjo); R5 : Pedagang pengecer Pasar Kecamatan/Pasar Desa (Kecamatan Wonoayu)

Tabel 6. Margin harga ikan kakap merah dan efisiensi pemasaran

\begin{tabular}{clllllc}
\hline No & Rantai & \multicolumn{2}{c}{ Rata-rata Harga } & $\begin{array}{c}\text { Tingkat Kenaikan } \\
\text { Harga }\end{array}$ & $\begin{array}{c}\text { Efisiensi } \\
\text { Pemasaran (Eps) }\end{array}$ \\
\hline 1 & R1 & Rp & 48.650 & & & \\
2 & R2 & $R p$ & 53.650 & Rp & 5.000 & \\
3 & R3 & $R p$ & 61.650 & Rp & 8.000 & \\
4 & R4 & $R p$ & 66.650 & Rp & 5.000 & \\
5 & R5 & $R p$ & 71.650 & Rp & 5.000 & \\
\hline
\end{tabular}

Keterangan: R1 : Produsen (nelayan/pemborong); R2 : Distributor/Supplyer; R3 : Agen Pasar Regional (Pasar Pabean Surabaya); R4 : Pedagang besar Pasar Kabupaten (Pasar Larangan Sidoarjo); R5 : Pedagang pengecer Pasar Kecamatan/Pasar Desa (Kecamatan Wonoayu) 
Tabel 7. Perhitungan kenaikan harga ikan swangi dan ikan kuniran

\begin{tabular}{|c|c|c|c|c|c|}
\hline No & Rantai & $\begin{array}{c}\text { Komposisi biaya } \\
\text { pemasaran }\end{array}$ & $\begin{array}{c}\text { Biaya } \\
\text { Pemasaran } \\
\text { (per-kg) ikan } \\
\text { swangi } \\
\text { (Rp.-) } \\
\end{array}$ & $\begin{array}{c}\text { Biaya } \\
\text { Pemasaran } \\
\text { (per-kg) ikan } \\
\text { kuniran } \\
\text { (Rp.-) } \\
\end{array}$ & $\begin{array}{l}\text { Tempat } \\
\text { Terjadi } \\
\text { Kenaikan }\end{array}$ \\
\hline 1 & $\mathrm{R} 1$ & $\begin{array}{l}\text { Biaya Melaut } \\
\text { Biaya Sortir } \\
\text { Biaya Angkut Kapal-TPI } \\
\text { Pengambilan keuntungan } \\
\text { Total biaya pemasaran/kg } \\
\text { ikan dari kapal-TPI }\end{array}$ & $\begin{array}{l}4.300 \\
150 \\
60 \\
700 \\
5.165\end{array}$ & $\begin{array}{l}4.300 \\
105 \\
60 \\
700 \\
5.165\end{array}$ & $\begin{array}{l}\text { Harga awal } \\
\text { dari nelayan } \\
\text { (penentu } \\
\text { harga } \\
\text { dari pihak } \\
\text { perusahaan) }\end{array}$ \\
\hline 2 & $\mathrm{R} 2$ & $\begin{array}{l}\text { Biaya es } \\
\text { Biaya upah sopir } \\
\text { biaya upah kuli angkut } \\
\text { Biaya Resiko } \\
\text { Biaya retribusi } \\
\text { Total biaya pemasaran/kg } \\
\text { ikan dari TPI-pabrik }\end{array}$ & $\begin{array}{l}345 \\
50 \\
150 \\
46 \\
405 \\
996\end{array}$ & $\begin{array}{l}345 \\
50 \\
150 \\
46 \\
480 \\
1.071\end{array}$ & $\begin{array}{l}\text { Distributor } \\
\text { (Pengepul) } \\
\text { dari TPI } \\
\text { menuju } \\
\text { pabrik } \\
\text { pengolahan }\end{array}$ \\
\hline Tota & a Biaya Pen & asaran Nelayan-Pabrik & 6.161 & 6.236 & \\
\hline No & Rantai & $\begin{array}{c}\text { Komposisi biaya } \\
\text { pemasaran }\end{array}$ & $\begin{array}{c}\text { Biaya } \\
\text { Pemasaran } \\
\text { (per-kg) ikan } \\
\text { (Rp.-) }\end{array}$ & Tempat Terj & di Kenaikan \\
\hline 1 & $\mathrm{R} 1$ & $\begin{array}{l}\text { Biaya Melaut } \\
\text { Biaya Angkut Kapal-TPI } \\
\text { Pengambilan keuntungan } \\
\text { Total biaya pemasaran/kg } \\
\text { ikan dari kapal-TPI } \\
\text { Pemberian es batu } \\
\text { Pengambilan keuntungan } \\
\text { Jasa mengangkut dari TPI } \\
\text { ke pick up }\end{array}$ & $\begin{array}{l}1.323 \\
60 \\
500 \\
1.883 \\
\\
360 \\
2.000 \\
150\end{array}$ & \multicolumn{2}{|c|}{ Harga awal dari nelayan } \\
\hline 2 & $\mathrm{R} 2$ & $\begin{array}{l}\text { Retribusi pembelian ikan } \\
\text { Biaya transport dari PPN- } \\
\text { Pasar regional } \\
\text { Biaya resiko } \\
\text { Total biaya pemasaran/kg } \\
\text { ikan } \\
\text { Jasa mengangkut dari } \\
\text { kendaraan ke pasar } \\
\text { Pemberian tambahan es } 10 \\
\text { balok }\end{array}$ & $\begin{array}{l}50 \\
400 \\
200 \\
3.160 \\
100 \\
120\end{array}$ & \multicolumn{2}{|c|}{$\begin{array}{l}\text { Distributor (Pengepul) dari } \\
\text { TPI menuju pasar ikan } \\
\text { regional }\end{array}$} \\
\hline 3 & R3 & $\begin{array}{l}\text { Pengambilan keuntungan } \\
\text { Retribusi harian pasar } \\
\text { Biaya resiko } \\
\text { Total biaya pemasaran/kg } \\
\text { ikan di Pasar regional } \\
\text { Pengambilan keuntungan } \\
\text { Pemberian es } 1 \text { balok }\end{array}$ & $\begin{array}{l}3000 \\
10 \\
300 \\
3230 \\
2000 \\
240 \\
100\end{array}$ & \multicolumn{2}{|c|}{$\begin{array}{l}\text { Pedagang ikan } \\
\text { pasar regional }\end{array}$} \\
\hline
\end{tabular}


Tabel 7 (lanjutan)

\begin{tabular}{|c|c|c|c|c|}
\hline No & Rantai & $\begin{array}{l}\text { Komposisi biaya } \\
\text { pemasaran }\end{array}$ & $\begin{array}{c}\text { Biaya } \\
\text { Pemasaran } \\
\text { (per-kg) ikan } \\
\text { (Rp.-) } \\
\end{array}$ & Tempat Terjadi Kenaikan \\
\hline 1 & $\mathrm{R} 4$ & $\begin{array}{l}\text { Retribusi harian pasar } \\
\text { Biaya resiko } \\
\text { Biaya transportasi pasar } \\
\text { regional-pasar kabupaten } \\
\text { Total biaya pemasaran } \\
\text { BBM }\end{array}$ & $\begin{array}{l}100 \\
500 \\
500 \\
3.340 \\
1.500\end{array}$ & $\begin{array}{l}\begin{array}{l}\text { Pedagang ikan di pasar } \\
\text { kabupaten }\end{array} \\
\end{array}$ \\
\hline 2 & R5 & $\begin{array}{l}\text { Pemberian es batu } \\
\text { Pengambilan keuntungan } \\
\text { Retribusi harian } \\
\text { total biaya pemasaran ikan }\end{array}$ & $\begin{array}{l}200 \\
2.000 \\
200 \\
3.900\end{array}$ & $\begin{array}{lr}\text { Pedagang } & \text { Kecil } \\
\text { Kecamatan / Desa) }\end{array}$ \\
\hline \multicolumn{3}{|c|}{$\begin{array}{l}\text { Total keseluruhan biaya pemasaran ikan } \\
\text { dari nelayan-konsumen }\end{array}$} & 15.513 & \\
\hline No & Rantai & $\begin{array}{l}\text { Komposisi biaya } \\
\text { pemasaran }\end{array}$ & $\begin{array}{c}\text { Biaya } \\
\text { Pemasaran } \\
\text { (per-kg) ikan } \\
\text { (Rp.-) } \\
\end{array}$ & Tempat Terjadi Kenaikan \\
\hline 1 & $\mathrm{R} 1$ & $\begin{array}{l}\text { Biaya Melaut } \\
\text { Pengambilan keuntungan } \\
\text { Total biaya pemasaran/kg } \\
\text { ikan dari kapal-TPI } \\
\text { Pemberian es } \\
\text { Pengambilan keuntungan }\end{array}$ & $\begin{array}{l}5.000 \\
5.000 \\
10.000 \\
360 \\
3.000\end{array}$ & Harga awal dari nelayan \\
\hline 2 & $\mathrm{R} 2$ & $\begin{array}{l}\text { Biaya buruh packing } \\
\text { BBM kendaraan } \\
\text { Retribusi pembelian ikan } \\
\text { di TPI } \\
\text { Total biaya pemasaran/kg } \\
\text { ikan } \\
\text { Jasa mengangkut dari } \\
\text { kendaraan ke pasar } \\
\text { Pemberian tambahan es }\end{array}$ & $\begin{array}{l}600 \\
400 \\
50 \\
4.410 \\
100 \\
120\end{array}$ & $\begin{array}{l}\text { Distributor (pengepul) dari } \\
\text { TPI menuju pasar ikan } \\
\text { regional }\end{array}$ \\
\hline 3 & R3 & $\begin{array}{l}\text { Pengambilan keuntungan } \\
\text { Retribusi harian pasar } \\
\text { Biaya resiko } \\
\text { Total biaya pemasaran } / \mathrm{kg} \\
\text { ikan di Pasar regional } \\
\text { Pengambilan keuntungan } \\
\text { Pemberian es } 1 \text { balok } \\
\text { Retribusi harian pasar } \\
\text { Rp.5.000 }\end{array}$ & $\begin{array}{l}5.000 \\
10 \\
500 \\
5.730 \\
\\
2.000 \\
240 \\
100\end{array}$ & $\begin{array}{l}\text { Pedagang ikan grosir di } \\
\text { pasar regional }\end{array}$ \\
\hline 4 & $\mathrm{R} 4$ & $\begin{array}{l}\text { Biaya resiko } \\
\text { Biaya transportasi pasar } \\
\text { regional-pasar kabupaten } \\
\text { Total biaya pemasaran } \\
\text { BBM }\end{array}$ & $\begin{array}{l}1.000 \\
100 \\
4.340 \\
1.500\end{array}$ & $\begin{array}{l}\text { Pedagang ikan di pasar } \\
\text { kabupaten }\end{array}$ \\
\hline 5 & R5 & $\begin{array}{l}\text { Pemberian es batu } \\
\text { Pengambilan keuntungan } \\
\text { Retribusi harian } \\
\text { total biaya pemasaran ikan }\end{array}$ & $\begin{array}{l}200 \\
2.000 \\
200 \\
3.900\end{array}$ & \multirow[t]{2}{*}{$\begin{array}{l}\text { Pedagang kecil (Pasar } \\
\text { Kecamatan/Desa) }\end{array}$} \\
\hline & $\begin{array}{r}\text { tal keselur } \\
\text { dari }\end{array}$ & $\begin{array}{l}\text { lan biaya pemasaran ikan } \\
\text { layan-konsumen }\end{array}$ & 18.380 & \\
\hline
\end{tabular}




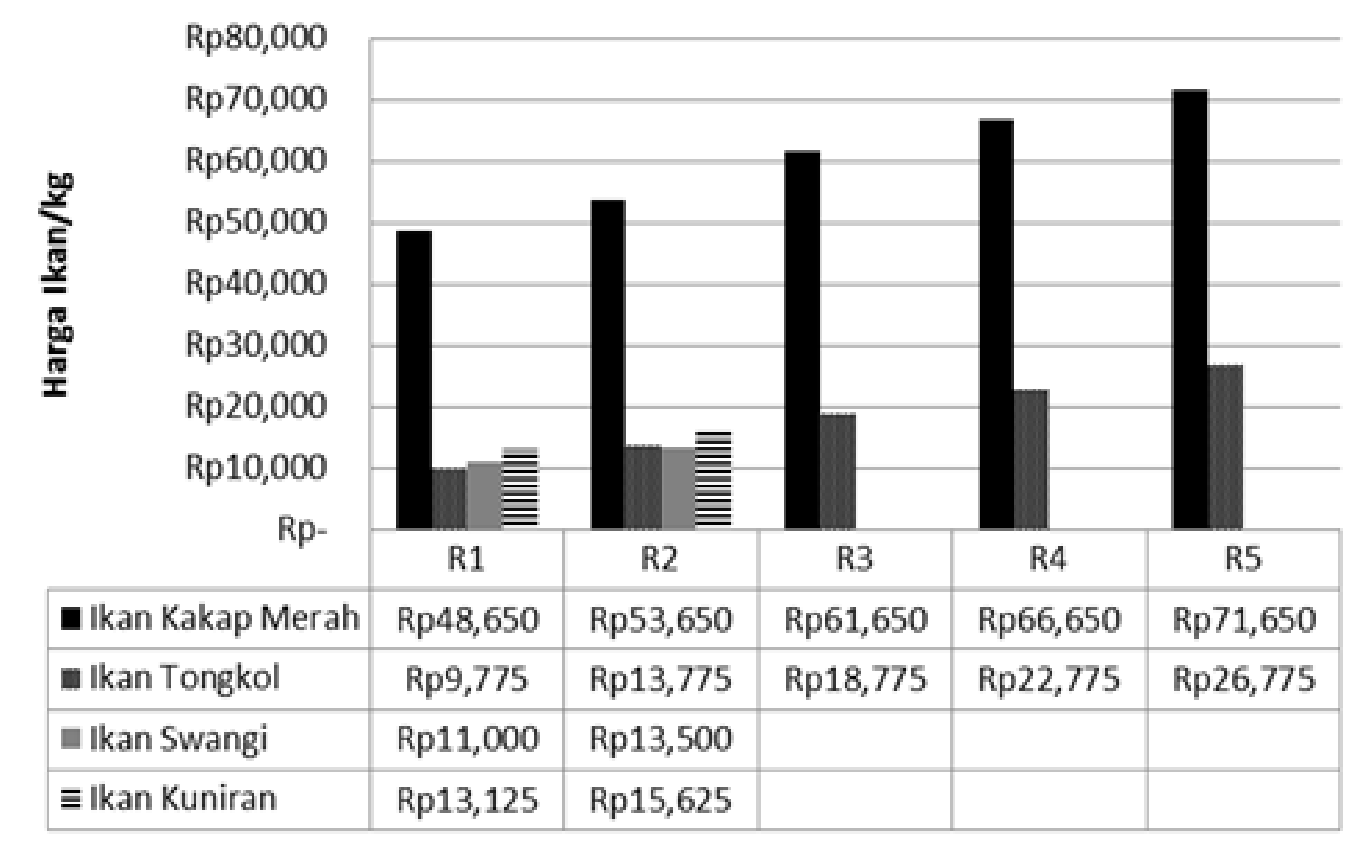

Gambar 7. Grafik tingkat kenaikan harga ikan di tiap rantai

Tabel 8. Nilai efisiensi pemasaran semua ikan

\begin{tabular}{clcl}
\hline No. & Nama Ikan & $\begin{array}{c}\text { Nilai Efisiensi } \\
\text { Pemasaran }\end{array}$ & Status Efisien \\
\hline 1. & Ikan Swangi & $45.44 \%$ & Tidak efisien \\
2. & Ikan Kuniran & $38.98 \%$ & Tidak efisien \\
3. & Ikan Tongkol & $57.94 \%$ & Tidak efisien \\
4. & Ikan Kakap Merah & $25.53 \%$ & Tidak efisien \\
\hline
\end{tabular}

\section{KESIMPULAN DAN SARAN}

\section{Kesimpulan}

Berdasarkan hasil penelitian dapat dinyatakan bahwa pemasaran ikan swangi, kuniran, tongkol dan kakap merah yang berasal dari PPN Brondong tidak efisien karena suatu produk dikatakan efisien dalam kegiatan pemasaran jika nilai efisiensi pemasaran kurang dari 5\% (Eps $<5 \%)$. Sedangkan nilai efisiensi pemasaran ikan swangi 45\%, kuniran 38.98\%, tongkol $57.94 \%$ dan kakap merah 25.53\%.

\section{Saran}

Perlu dilakukannya peningkatan efisiensi biaya dalam pemsaran ikan yang berasal dari PPN Brondong berupa peningkatan fasilitas pelabuhan yang ada saat ini. Selain itu, perlu penelitian lebih lanjut untuk mengetahui faktor-faktor yang mempengaruhi tingkat efisiensi pemasaran ikan yang berasal dari PPN Brondong serta menetukan strateginya.

\section{DAFTAR PUSTAKA}

Ahmad M. 2012. Kesangkilan pasar hasil perikanan di kawasan pesisir. Jurnal Dinamika Pertanian. Vol 28: 73-82.

Anggrahini WP. 2012. Kajian efektivitas dan efisiensi kapal navigasi dalam rangka distribusi logistik pada distrik navigasi Surabaya. Jurnal Penelitian Transportasi Laut. Vol 13: 1-15.

Cenini P. 2012. Supply chain management. www.fao.org. [diakses pada tanggal 12 November 2012].

Deswindi L. 2007. Kecepatan tingkat penerimaan dan perilaku konsumen terhadap produk lama yang mengalami perubahan dan produk inovasi baru dalam upaya memasuki dan merebut pasar. Business \& management 
Journal Bunda Multa.Vol 3:19-25 .

Hanafiah AM, Saefuddin AM. 2006. Tataniaga Hasil Perikanan. Jakarta: UI Press.

Hansen, Don R, Maryanne MM. 2004. Akuntansi Manajemen. Jakarta: Salemba Empat.

Hapsari TD. 2013. Distribusi dan margin pemasaran hasil tangkapan ikan tongkol (Euthynus affinis) di TPI Ujungbatu Jepara. Aquasains (Jurnal Ilmu Perikanan dan Sumberdaya Perairan).Vol 2:132-138.

Irawan B. 2007. Fluktuasi harga, transmisi harga dan marjin pemasaran sayuran dan buah. Analisis Kebijakan Pertanian Vol 5: 358-373.

Johanson D. 2013. Analisis efisiensi pola distribusi hasil penangkapan ikan nelayan Kecamatan Kahayan Kuala Kabupaten Pulang Pisau. Jurnal Sains Manajemen. Vol 1:96-106.

Oktariza W, Achmad F, Istiqlaliyah M. Yatri IK, Heri A. 1996. Studi Distribusi Pemasaran Hasil Perikanan Laut dari
Pelabuhan Ratu, Sukabumu, Jawa Barat. Buletin Ekonomi Perikanan. Vol. 2 (2): 34-43.

Rasuli N, Muh. Amir S, Kartika E. 2007. Analisis margin pemasaran telur itik di Kelurahan Borongloe, Kecamatan Bontomarannu, Kabupaten Gowa. Jurnal Agrisistem. Vol 3:36-43.

Setiawan HH, Suhadak, Nengah S. 2014. Analisis biaya pemasaran sebagai salah satu alat untuk pengendalian biaya komersil. Jurnal Administrasi Bisnis (JAB). Vol 13:1-7.

Sobariah, Ganjar W. 2013. Analisis margin pemasaran ikan hias pada enam pasar di Kota/Kabupaten Bogor. Jurnal Penyuluhan Perikanan dan Kelautan Vol. 7: 53-63

Tahir AG, Dwidjono HD, Jangkung HM, Jamhari. 2011. Metode analisis efisiensi pemasaran kedelai di Sulawesi Selatan. Informasi Pertanian Vol 20:47-57. 